\title{
INHIBITION OF THE FORMATION OF AMYLOID-LIKE FIBRILS WITH SPICES, ESPECIALLY CLOVES
}

\author{
Márta Kotormán, ${ }^{1 *}$ AleXandra VARGa, ${ }^{1}$ \\ Phanindra Babu Kasi ${ }^{1,2}$ and János NemcsóK ${ }^{3}$ \\ ${ }^{1}$ Department of Biochemistry and Molecular Biology, Faculty of Science and Informatics, \\ University of Szeged, Középfasor 52, H-6726 Szeged, Hungary \\ ${ }^{2}$ Doctoral School in Biology, Faculty of Science and Informatics, \\ University of Szeged, Szeged, Hungary \\ ${ }^{3}$ Department of Biology, Pedagogical Faculty, Selye János University, \\ Bratislavská cesta 3322, SK-94501 Komarno, Slovak Republic
}

\begin{abstract}
During the study of inhibition of amyloid fibril formation, $\alpha$-chymotrypsin protein was developed in 55\% ethanol at $\mathrm{pH}$ 7.0. We investigated the inhibitory effect of different spices on amyloid fibril formation using turbidity measurements and Congo red binding assays. We found that all spices except the black pepper and caraway seed prevented fibril formation. The highest inhibition was measured with the clove, which reduced the amount of aggregates by $90 \%$. We studied the inhibitory effect of the cloves at different concentrations on aggregation, it was found that the inhibitory activity of clove is dependent on concentration. We have measured the total phenolic content of the spice extracts too. Based on all these findings we have come to the following conclusion: Our results indicate that spices can contain other compounds too - not only phenolic compounds - which influence the formation of amyloid fibrils, and the effectiveness of various phenolic compounds are different.
\end{abstract}

Keywords: $\alpha$-chymotrypsin - amyloid fibrils - clove - polyphenols - spice

\section{INTRODUCTION}

The protein aggregate, which shows fibrillar morphology, has a $\beta$-plate structure, and is typically stained with Congo red or thioflavin is called amyloid fibril [4]. The accumulation of amyloid fibrils may be due to the emergence of many illnesses affecting millions of people, such as spongiform encephalitis, Alzheimer's disease, Parkinson's or Huntington's disease, type II diabetes, primary and secondary systemic amyloidosis [31]. Certain globular proteins are able to form amyloid fibrils under appropriate conditions. These conditions include high pressure, high temperature, near isoelectric point, presence of organic solvents and high concentration of the protein. These factors contribute to the partial unfolding of the protein and certain mutations that increase the destabilization of the native structure, thus increasing the aggregation tendency of proteins [4]. Thus, important information on the formation of amyloid fibrils can be obtained by studying proteins that are not related to any known protein conformational disease [17].

\footnotetext{
*Corresponding author, e-mail: kotorman@expbio.bio.u-szeged.hu
} 
Spices contain important bioactive compounds that may be important for the prevention and treatment of various diseases without undesirable side effects $[8,12]$. Bioactive molecules are able to bind to the native structure of the protein. They are able to stabilize their conformation by enhancing the energy barrier of fibril formation [9]. Spices contain many bioactive compounds that may be potential therapeutic agents in the treatment of various amyloidoses $[8,12]$. The main components of spice extracts are biologically active flavonoids, isoflavonoids, tannins, coumarins, glycosides, di- and triterpenoids, phytosterols, tocopherols, phenolic acids, alkaloids, carotenes, vitamins and other compounds [22,33]. Flavonoids are able to cross the bloodbrain barrier [30]. Polyphenols are secondary metabolites produced by plants, an average person consumes $1-2 \mathrm{~g}$ daily as part of a normal diet. Compounds which, on their aromatic rings, have one or more hydroxyl groups are called polyphenols. The beneficial effect of spices on health is related to the content of their high polyphenolic compounds [11]. The aromatic rings of polyphenols may interact with the aromatic side chains of amyloidogenic proteins, they prevent $\pi-\pi$ interactions and block self-organizing processes [2]. The position of hydroxyl groups was found be decisive for the anti-amyloidogenic properties and not their number [28]. Curcuma is polyphenol found in curcuma or otherwise known as Indian Curcuma (Curcuma longa). By in vivo and in vitro studies curcuma inhibited fibril and oligomer formation during amyloid aggregation in a variety of amyloid fibril-capable proteins such as $\alpha$-synuclein, amylin, amyloid $\beta$, prion protein and egg protein lysozyme, transthyretin and human islet amyloid polypeptide (hIAPP) [5, 26, 36, 39]. Rosemary acid is a polyphenol found in lemon grass, rosemary, oregano, common sage, thyme and peppermint [10]. Rosemarinic acid is capable of preventing amyloid $\beta$ protein induced neurotoxicity on PC12 cell lines and protects against reactive oxygen radicals [13]. Rosemary acid can inhibit the formation of amyloid conformation of some amyloidogenic proteins such as the hIAPP, amyloid $\beta$ protein and amylin [24]. The presence of flavonoids and other antioxidant compounds has been demonstrated, for example in basil, chives, coriander, dill, lovage, parsley, rosemary, sage, mint, tarragon and thyme [14]. Pinocembrin is a natural flavonoid, present in ginger and marjoram [18]. Pinocembrin is a promising candidate in the prevention and therapy of Alzheimer's disease [20]. Na and colleagues' results show that 6-shogaol, a ginger component, is a novel potential therapeutic agent for the treatment of various neurodegenerative diseases, including Alzheimer's disease [23]. The aqueous extract of cloves is rich in polyphenols [32]. Clove oil contains high concentrations of eugenol [33]. Eugenol can cross the blood-brain barrier [19]. Eugenol prevents the formation of amyloid fibrillation of insulin and serum albumin. Eugenol stabilizes the native structure of proteins and delays the formation of native conformation of proteins into $\beta$-rich amyloid fibrils [7].

Amyloid fibrils of various proteins have the ability to bind small, planar molecules such as, for example, the Congo red (CR) amyloid-specific dye [6]. CR is one of the most commonly used dyes that are suitable for identifying amyloid fibrils [35].

We aimed at studying the inhibitory effect of various spices on the formation of amyloid fibrils. Based on previous experiments carried out by our group, it is known 
that $\alpha$-chymotrypsin produces amyloid-like fibrils in $55 \%$ ethanol at $\mathrm{pH} 7.0$ after 1 day of incubation [29], so it can be used as a model protein for the study of the formation of fibrils, as well as the effects of anti-amyloidogenic agents.

\section{MATERIALS AND METHODS}

The $\alpha$-chymotrypsin (EC 3.4.21.1) was marketed by Sigma-Aldrich Kft. Spices used were commercially available spices. The grounded black pepper (Piper nigrum L.), ginger (Zingiber officinale Roscoe), anise (Pimpinella anisum L.), white pepper (Piper nigrum L.), nutmeg (Myristica fragrans), cumin (Cuminum cyminum), whole juniper berries (Juniperus communis L.), coriander seeds (Coriandrum sativum L.), crumbled savory (Satureja hortensis L.), marjoram (Majorana hortensis M.) and oregano (Origanum vulgare) was packaged by Szilasfood Kft. (2143 Kistarcsa, Nagytarcsai út 6.). The grounded safflower (Carthamus tinctorius L.), turmeric (Curcuma longa L.), cinnamon (Cinnamomum cassia B.), bay leaf (Laurus nobilis L.), allspice (Pimenta racemosa Mil L.) and crumbled basil (Ocimum basilicum) were imported by R COOP3 Kft. (6771 Szeged-Szőreg T. 2). The grounded caraway seed (Carum carvi), rosemary (Rosmarinus officinalis L.), cayenne pepper (Capsicum annuum, Cayenne'), cloves (Syzygium aromaticum L.), sliced wild garlic (Allium ursinum L.), parsley (Petroselinum crispum), sage (Salvia officinalis L.), crumbled thyme (Thymus serpyllum L.), dill (Anethum graveolens L.), tarragon (Artemisia dracunculus L.), lovage (Levisticum officinale), true saffron (Crocus sativus) were produced by Kotányi Hungária Kft. (1146 Budapest, Hermina út 17.). The crumbled celery leaf (Apium graveolens L.) and entire hibiscus flower (Hibiscus rosa-sinensis) were produced by Toldi Füszer és Delicates Bt. (1103 Budapest, Gyömrői út 150).

\section{Spice extracts}

Based on references other researches also used the hot water extract method with spices [15,34]. To prepare spice extracts, $6 \mathrm{ml}$ of distilled water was added to $600 \mathrm{mg}$ of spice and then was brought to boil. We waited for the extracts to cool down to room temperature, then centrifuged them. The supernatants were stored in the freezer until we started to use them. Supernatants were used for the measurements. The supernatants were further diluted with the distilled water as needed before use.

\section{Turbidity measurement}

Detection of amyloid growth is commonly carried out by measurement of solution turbidity [40]. During turbidity measurements, using a Cecil CE-5501 spectrophotometer, the extinction values were measured at $350 \mathrm{~nm}$ using a cuvette of $1 \mathrm{~cm}$ path length. The $\alpha$-chymotrypsin concentration was $0.15 \mathrm{mg} / \mathrm{ml}$ in $55 \%$ ethanol in $0.01 \mathrm{M}$ 
phosphate buffer at $\mathrm{pH}$ 7.0. The samples were incubated for 24 hours at $24{ }^{\circ} \mathrm{C}$ before the measurements. For turbidity measurements, the following incubation mixtures were measured: $200 \mu \mathrm{l}$ water/spice extract $(\times 100), 200 \mu \mathrm{l}$ of $0.05 \mathrm{M}$ buffer $\mathrm{pH}=7.0$ $\left(\mathrm{Na}_{2} \mathrm{HPO}_{4} / \mathrm{KH}_{2} \mathrm{PO}_{4}\right), 550 \mu \mathrm{l}$ of ethanol, $50 \mu \mathrm{l} \alpha$-chymotrypsin $(3 \mathrm{mg} / \mathrm{ml}$, in $0.001 \mathrm{~N}$ $\mathrm{HCl}$ ). Significance was determined by one-way analysis of variance (ANOVA).

\section{Determination of total phenolic content}

The total phenolic content of spice extracts was determined utilizing the FolinCiocalteu colorimetric method of Waterhouse [37]. The samples were kept for $2 \mathrm{~h}$ at $24^{\circ} \mathrm{C}$, and absorbance was measured at $765 \mathrm{~nm}$. For calibration, gallic acid solutions of different concentrations $(0-50 \mathrm{mg} / \mathrm{l})$ were used. The total phenolic content was expressed as mg gallic acid equivalents (GAE) per 1 of spice extracts. The data presented are the average of three measurements.

\section{CR binding}

The amyloid-specific CR binding was measured in the presence of $0.005 \mathrm{M}$ phosphate buffer and $150 \mathrm{mM} \mathrm{NaCl}$ at $\mathrm{pH}$ 7.0. The protein sample was incubated in the presence of $55 \%$ ethanol at $24{ }^{\circ} \mathrm{C}$ for 24 hours and then $200 \mu$ was mixed with 800 $\mu \mathrm{l}$ of CR solution $(7.7 \mu \mathrm{M})$. Absorption was measured after 15 minutes of incubation, as this time was needed to bind the dye to the protein. Using a $1 \mathrm{~cm}$ cuvette, the absorption spectrum was recorded in a 400-600 nm wavelength range using a Hitachi U-2000 spectrophotometer. In the presence of amyloid fibrils, the shift of the absorption maximum to a higher wavelength (red shift) and the absorption intensity increase were measured. The absorption maximum of CR increased from $490 \mathrm{~nm}$ to $510 \mathrm{~nm}$ in the presence of amyloid fibrils. If the spectra of the $\mathrm{CR}$ and protein-containing samples are subtracted from the absorption spectra of the samples containing the enzyme, the CR, and the spice extract, we obtain the differential spectrum which reflects the spectral change of the binding of the CR to the amyloid fibrils.

\section{RESULTS}

\section{$\alpha$-Chymotrypsin aggregation}

The effect of amyloid fibrillation on 32 types of spices in Hungary was studied with $\alpha$-chymotrypsin model protein. Turbidity measurements took place at $\mathrm{pH} 7.0$ in the presence of $0.01 \mathrm{M} \mathrm{Na}_{2} \mathrm{HPO}_{4} / \mathrm{KH}_{2} \mathrm{PO}_{4}$ buffer at $55 \%$ ethanol concentration in the presence and absence of spice extract $(\times 500)$ at $0.15 \mathrm{mg} / \mathrm{ml}$ protein concentration. We calculated the percentage of inhibition of aggregation based on turbidity measurements. We measured the total concentration of phenolic compounds of all spice 

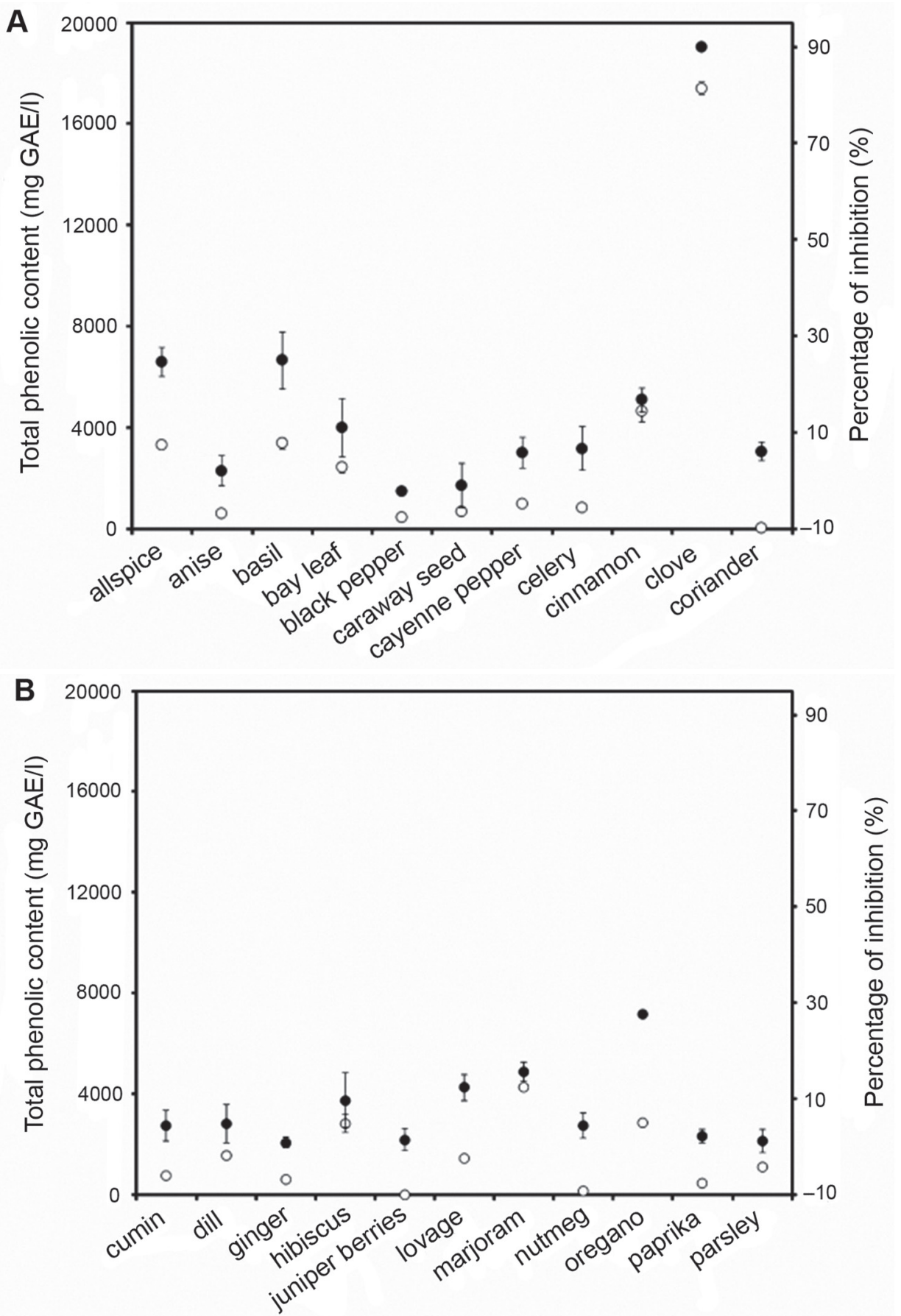

Fig. 1A, $B$ 


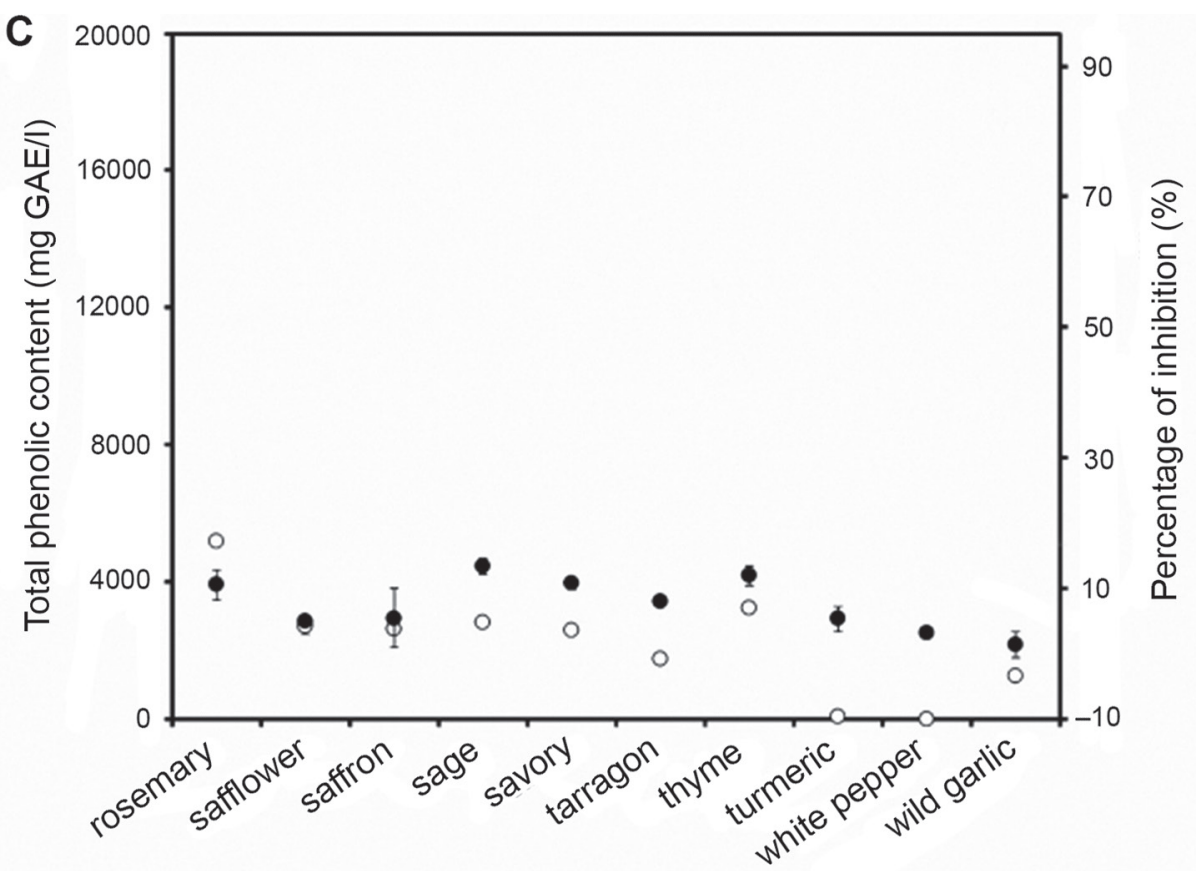

Fig. 1. The change in percentage of inhibition with the total phenolic content. Percentage of inhibition in $55 \%$ ethanol $(\bigcirc)$ and total phenolic content $(\bigcirc)$. Spice extracts were diluted $\times 500$. Protein concentration was $0.15 \mathrm{mg} / \mathrm{ml}$. All data were presented as mean \pm standard error of the mean (SEM) from three independent measurements

extracts. The total concentrations of phenolic compounds of different spice extracts ranged from 0 to $17,408 \pm 264 \mathrm{mg}$ GAE$/ 1$. Our measurement results are shown in Fig. 1. All data were presented as mean \pm standard error of the mean (SEM) from three independent measurements. Black pepper and caraway seed did not affect the formation of amyloid fibrils. Wild garlic, ginger, anise, parsley, white pepper, nutmeg, safflower, turmeric, juniper berries, tarragon, saffron, cayenne pepper, paprika, celery, dill, and hibiscus between $1.0 \pm 1.1$ and $9.8 \pm 5.8 \%$, thyme, savory, lovage, rosemary, cinnamon, sage, majoran, bay leaves between $10.6 \pm 2.3$ and $16.8 \pm 2.4 \%$, allspice, oregano, basil $24.7 \pm 3.0$ to $28 \pm 0.7 \%$ reduced the aggregation rate. The largest inhibition was measured for clove, reducing the aggregation by $90 \pm 0.6 \%$. So we investigated the effect of clove on aggregation in further studies.

Turbidity measurements to detect the inhibitory effect of clove at different concentrations were performed at $\mathrm{pH} 7.0$ in the presence and absence of $0.01 \mathrm{M} \mathrm{Na}_{2} \mathrm{HPO}_{4} /$ $\mathrm{KH}_{2} \mathrm{PO}_{4}$ buffer at $55 \%$ ethanol concentration in the presence and absence of spice extract at a protein concentration of $0.15 \mathrm{mg} / \mathrm{ml}$. Our measurement results are shown in Fig. 2A. The measurements were performed with $\times 500, \times 2000, \times 4000, \times 8000$ and $\times 16,000$ dilutions. It has been shown that the degree of inhibition of amyloid fibril formation is proportional to the concentration of the spice used. We investigated the 
efficiency of specific compounds: caffeic acid and rosmarinic acid, as positive control too. The highest concentrations of positive controls were selected based on preliminary (non-published) measurements. Our results indicated, that the degree of inhibition of amyloid fibril formation is proportional to the concentration of the positive control compounds used (Fig. 2B).
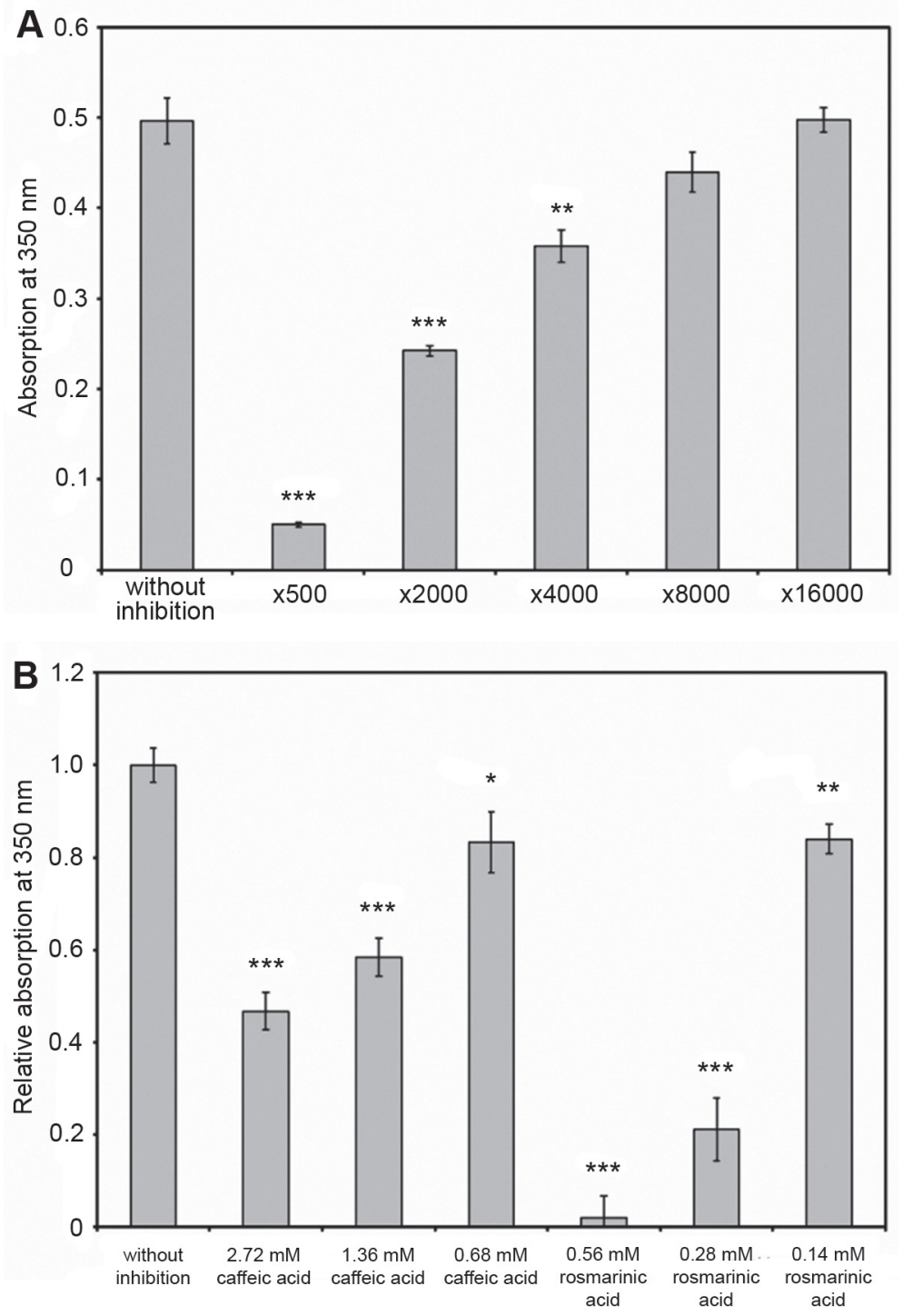

Fig. 2. Change in absorbance at $350 \mathrm{~nm}$ at $24{ }^{\circ} \mathrm{C}$ at $\mathrm{pH} 7.0$ at $55 \%$ ethanol concentration in the presence and absence of clove extracts (A), caffeic acid and rosmarinic acid (B) in various dilutions after $24 \mathrm{~h}$ incubation. $\alpha$-chymotrypsin concentration: $0.15 \mathrm{mg} / \mathrm{ml}$. All data were presented as mean \pm standard error of the mean (SEM) from three independent measurements. Significance was defined as $* * * \mathrm{P}<0.001$, $* * \mathrm{P}<0.01$ and $* \mathrm{P}<0.05$ 


\section{CR binding examination}

The results of the CR binding experiments are shown in Figure 3. The figures show that in the presence of amyloid fibrils at $55 \%$ ethanol concentration, the maximum absorbance of the conglomerate was greater wavelength and the intensity also increased. For the cloves we examined, we tested the CR binding in 500, 2000 and 4000 fold dilutions in $55 \%$ ethanol solvents and the difference spectra were calculated (Fig. 3). Differential spectra were calculated by extracting the convex and $\alpha$-chymotrypsin spectra from $\alpha$-chymotrypsin + CR spectrum. The shape of the differential spectra reflects the spectral change in the presence of amyloid fibrils. By studying the conglomeric binding, it was found that the degree of inhibition of amyloid fibril formation was proportional to the concentration of spices used.

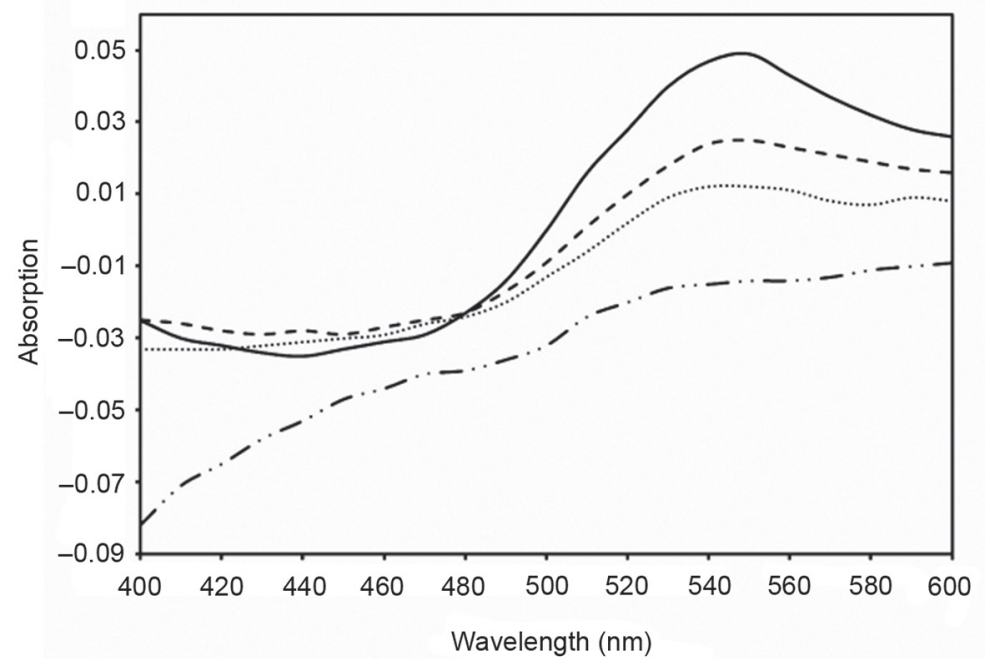

Fig. 3. Congo red differential spectra. Clove in $500 \times$ dilution (dashed-dotted line), in $2000 \times$ dilution (dotted line), and in $\times 4000$ dilution (dashed line) and without inhibition (solid line)

\section{DISCUSSION}

Spices are suitable for the inhibition of amyloid formation [21] due to their high polyphenol content. An important approach to therapeutic agents is the use of small molecules that can inhibit the formation of amyloid fibrils. Many polyphenols have been shown to inhibit fibril formation in vitro [27]. Caffeic acid and rosmarinic acid, which we used as positive control, have also been shown to have anti-amyloidogenic effects. Caffeic acid inhibited the amyloid formation of hIAPP [3]. Rosmarinic acid inhibited the aggregation of amyloid $\beta$-protein [25]. In clove there are many different polyphenols including gallic acid, ellagic acid, quercetin glucoside, ellagic acid derivatives and other unidentified polyphenols [1]. 
For juniper berries and white pepper extracts, for example, we did not have the ability to measure phenolic component content, yet these extracts had a low degree of inhibition of fibril formation. This can only be interpreted that other non-phenolic compounds can play a role in inhibiting fibril formation too. In fact, black pepper and cumin extracts contained some phenolic components, but did not have any effect on fibril formation in $500 \times$ dilution. Thus, the effectiveness of various phenolic compounds is also different.

$\mathrm{CR}$ is a widely used diazo dye. A dye that can be specifically bound to the $\beta$-plate structure that also incorporates amyloid fibrils, which is thus suitable for detecting the presence of amyloid fibrils. It is accompanied by a spectral change in the binding of the $\mathrm{CR}$ amyloid to fibrils. In the presence of fibrils, it shows a red shift, i.e. the maximum absorbance of the conglomerate is displaced from $490 \mathrm{~nm}$ to $510 \mathrm{~nm}$, and its absorption intensity increases [39]. The CR bonding test has many advantages over other test methods. Only a spectrophotometer is needed, so it is widely used and does not require expensive reagents or radioactive labeling so it can be easily and quickly applied. The biggest advantage, however, is that it provides a quantitative comparison of the dye-amyloid interaction [16].

\section{ACKNOWLEDGEMENTS}

This work was supported by project EFOP-3.6.1-16-2016-00008.

\section{REFERENCES}

1. Adefegha, S. A., Oboh, G. (2012) In vitro inhibition activity of polyphenol-rich extracts from Syzygium aromaticum (L.) Merr. \& Perry (Clove) buds against carbohydrate hydrolyzing enzymes linked to type 2 diabetes and $\mathrm{Fe}^{2+}$-induced lipid peroxidation in rat pancreas. Asian Pac. J. Trop. Biomed. 2, 774-781.

2. Cheng, B., Gong, H., Xiao, H., Petersen, R. B., Zheng, L., Huang, K. (2013) Inhibiting toxic aggregation of amyloidogenic proteins: A therapeutic strategy for protein misfolding diseases. Biochim. Biophys. Acta-Gen. Subj. 1830, 4860-4871.

3. Cheng, B., Liu, X., Gong, H., Huang, L., Chen, H., Zhang, X., Li, C., Yang, M., Ma, B., Jiao, L., Zheng, L., Huang, K. (2011) Coffee components inhibit amyloid formation of human islet amyloid polypeptide in vitro: possible link between coffee consumption and diabetes mellitus. J. Agric. Food Chem. 59, 13147-13155.

4. Chiti, F., Dobson, C. M. (2006) Protein misfolding, functional amyloid, and human disease. Аnnu. Rev. Biochem. 75, 333-366.

5. Daval, M., Bedrood, S., Gurlo, T., Huang, C. J., Costes, S., Butler, P. C., Langen, R. (2010) The effect of curcumin on human islet amyloid polypeptide misfolding and toxicity. Amyloid 17, 118-128.

6. Dec, R., Babenko, V., Dzwolak, W. (2016) Molecules of Congo red caught hopping between insulin fibrils: a chiroptical probe of the dye-amyloid binding dynamics. RSC Advances 6, 97331-97337.

7. Dubey, K., Anand, B. G., Shekhawat, D. S., Kar, K. (2017) Eugenol prevents amyloid formation of proteins and inhibits amyloid-induced hemolysis. Sci. Rep. 7, 40744.

8. Essa, M. M., Vijayan, R. K., Castellano-Gonzalez, G., Memon, M. A., Braidy, N., Guillemin, G. J. (2012) Neuroprotective effect of natural products against Alzheimer's disease. Neurochem. Res. 37, 1829-1842. 
9. Härd, T., Lendel, C. (2012) Inhibition of amyloid formation, J. Mol. Biol. 421, 441-465.

10. Hazavehei, S. M. (2012) Effect of two herbal polyphenol compounds on human amylin amyloid formation and destabilization. J. Med. Plants Res. 6, 3207-3212.

11. Hossain, M. B., Patras, A., Barry-Ryan, C., Martin-Diana, A. B., Brunton, N. P. (2011) Application of principal component and hierarchical cluster analysis to classify different spices based on in vitro antioxidant activity and individual polyphenolic antioxidant compounds. J. Funct. Foods 3, 179-189.

12. Iriti, M., Vitalini, S., Fico, G., Faoro, F. (2010) Neuroprotective herbs and foods from different traditional medicines and diets. Molecules 15, 3517-3555.

13. Iuvone, T., De Filippis, D., Esposito, G., D'Amico, A. (2006) The spice sage and its active ingredient rosmarinic acid protect $\mathrm{PC} 12$ cells from amyloid-beta peptide-induced neurotoxicity. J. Pharmacol. Exp. Ther. 317, 1143-1149.

14. Justesen, U., Knuthsen, P. (2001) Composition of flavonoids in fresh herbs and calculation of flavonoid intake by use of herbs in traditional Danish dishes. Food Chem. 73, 245-250.

15. Kim, I. S., Yang, M. R., Lee, O. H., Kang, S. N. (2011) Antioxidant activities of hot water extracts from various spices. Int. J. Mol. Sci. 12, 4120-4131.

16. Klunk, W. E., Jacob, R. F., Mason, R. P. (1999) Quantifying amyloid beta-peptide (Abeta) aggregation using the Congo red-Abeta (CR-abeta) spectrophotometric assay. Anal. Biochem. 266, 66-76.

17. Knowles, T. P., Vendruscolo, M., Dobson, C. M. (2014) The amyloid state and its association with protein misfolding diseases. Nat. Rev. Mol. Cell Biol. 15, 384-96.

18. Lan, X., Wang, W., Li, Q., Wang, J. (2016) The natural flavonoid pinocembrin: Molecular targets and potential therapeutic applications. Mol. Neurobiol. 53, 1794-1801.

19. Liang, Z. H., Cheng, X. H., Ruan, Z. G., Wang, H., Li, S. S., Liu, J., Li, G. Y., Tian, S. M. (2015) Protective effects of components of the Chinese herb grassleaf sweetflag rhizome on PC12 cells incubated with amyloid-beta42. Neural Regen. Res. 10, 1292-1297.

20. Liu, R., Wu, C., Zhou, D., Yang, F., Tian, S., Zhang, L., Zhang, T., Du, G. (2012) Pinocembrin protects against $\beta$-amyloid-induced toxicity in neurons through inhibiting receptor for advanced glycation end products (RAGE)-independent signaling pathways and regulating mitochondrionmediated apoptosis. BMC Med. 10, 105.

21. Mirmosayyeb, O., Tanhaei, A., Sohrabi, H. R., Martins, R. N., Tanhaei, M., Najafi, M. A., Safaei, A., Meamar R. (2017) Possible role of common spices as a preventive and therapeutic agent for Alzheimer's disease. Int. J. Prev. Med. 8, 5.

22. Misharina, T. A. (2016) Antiradical properties of essential oils and extracts from coriander, cardamom, white, red, and black peppers. Appl. Biochem. Microbiol. 52, 79-86.

23. Na, J. Y., Song, K., Lee, J. W., Kim, S., Kwon, J. (2016) 6-Shogaol has anti-amyloidogenic activity and ameliorates Alzheimer's disease via CysLT1R-mediated inhibition of cathepsin B. Biochem. Biophys. Res. Commun. 477, 96-102.

24. Ngoungoure, V. L. N., Schluesener, J., Moundipa, P. F. S., Chluesener, H. (2015) Natural polyphenols binding to amyloid: A broad class of compounds to treat different human amyloid diseases. Mol. Nutr. Food Res. 59, 8-20.

25. Ono, K., Li, L., Takamura, Y., Yoshiike, Y., Zhu, L., Han, F., Mao, X., Ikeda, T., Takasaki, J., Nishijo, H., Takashima, A., Teplow, D. B., Zagorski, M. G., Yamada, M. (2012) Phenolic compounds prevent amyloid $\beta$-protein oligomerization and synaptic dysfunction by site-specific binding. J. Biol. Chem. 287, 14631-14643.

26. Pandey, N., Strider, J., Nolan, W. C., Yan, S. X., Galvin, J. E. (2008) Curcumin inhibits aggregation of alpha-synuclein. Acta Neuropathol. 115, 479-489.

27. Porat, Y., Abramowitz, A., Gazit, E. (2006) Inhibition of amyloid fibril formation by polyphenols: structural similarity and aromatic interactions as a common inhibition mechanism. Chem. Biol. Drug Des. 67, 27-37.

28. Porzoor, A., Alford, B., Hügel, H., Grando, D., Caine, J., Macreadie, I. (2015) Anti-amyloidogenic properties of some phenolic compounds. Biomolecules 5, 505-527. 
29. Simon, L. M., Laczkó, I., Demcsák, A., Tóth, D., Kotormán, M., Fülöp, L. (2012) The formation of amyloid-like fibrils of $\alpha$-chymotrypsin in different aqueous organic solvents. Protein Pept. Lett. 19, 544-550.

30. Solanki, I., Parihar, P., Mansuri, M. L., Parihar, M. S. (2015) Flavonoid-based therapies in the early management of neurodegenerative diseases. Adv. Nutr. 6, 64-72.

31. Stefani, M. (2004) Protein misfolding and aggregation: new examples in medicine and biology of the dark side of the protein world. Biochim. Biophys. Acta 1739, 5-25.

32. Suantawee, T., Wesarachanon, K., Anantsuphasak, K., Daenphetploy, T., Thien-Ngern, S., Thilavech, T., Pasukamonset, P., Ngamukote, S., Adisakwattana, S. (2015) Protein glycation inhibitory activity and antioxidant capacity of clove extract. J. Food Sci. Technol. 52, 3843-3850.

33. Torres, J. E. D., Gassara, F., Kouassi, A. P., Brar, S. K., Belkacemi, K. (2017) Spice use in food: Properties and benefits. Crit. Rev. Food Sci. Nutr. 57, 1078-1088.

34. Touba, E. P., Zakaria, M., Tahereh, E. (2012) Anti-fungal activity of cold and hot water extracts of spices against fungal pathogens of Roselle (Hibiscus sabdariffa) in vitro. Microb. Pathog. 52, $125-129$.

35. de Vasconcelos, D. N., Ximenes, V. F. (2015) Albumin-induced circular dichroism in Congo red: Applications for studies of amyloid-like fibril aggregates and binding sites. Spectrochim. Acta Part A Mol. Biomol. Spectrosc. 150, 321-330.

36. Wang, S. S., Liu, K. N., Lee, W. H. (2009) Effect of curcumin on the amyloid fibrillogenesis of hen egg-white lysozyme. Biophys. Chem. 144, 78-87.

37. Waterhouse, A. L. (2002) Determination of Total Phenolics. In Current Protocols in Food Analytical Chemistry John Wiley \& Sons, Inc., Hoboken, NJ, USA. (doi:10.1002/0471142913.faa0101s06)

38. Wu, C., Scott, J., Shea, J. E. (2012) Binding of congo red to amyloid protofibrils of the Alzheimer $\mathrm{A} \beta(9-40)$ peptide probed by molecular dynamics simulations. Biophys. J. 103, 550-557.

39. Zhang, C., Browne, A., Child, D., Tanzi, R. E. (2010) Curcumin decreases amyloid-beta peptide levels by attenuating the maturation of amyloid-beta precursor protein. J. Biol. Chem. 285, 28472-28480.

40. Zhao, R., So, M., Maat, H., Ray, N. J., Arisaka, F., Goto, Y., Carver, J. A., Hall, D. (2016) Measurement of amyloid formation by turbidity assay-seeing through the cloud. Biophys. Rev. 8, 445-471. 